\title{
Problems of Social-Economic and Demographic Development of Agricultural Population (Based on the Data of the Republic of Tatarstan)
}

\author{
${ }^{1}$ Niyaz K. Gabdrakhmanov, ${ }^{2}$ VladimirA.Rubtzov, ${ }^{3}$ Niyaz M. Biktimirov, ${ }^{4}$ Eduard I. Baibakov \\ 1, 2, 3, ${ }^{4}$ Kazan Federal University \\ E-mail: nz99nz@yandex.ru, Contact: 89046626025
}

\section{Received: 21st October 2017 Accepted: 16th November 2017, Published: 31st December 2017}

\begin{abstract}
This study is aimed at identifying contemporary problems of socio-economic and demographic development of the rural population in one of the regions of Russia. The high economic potential of rural areas of the Republic of Tatarstan is revealed in the work. The rural population in Tatarstan is decreasing quite rapidly, and the potential of rural areas is not always properly used. In this study, the example of the Republic of Tatarstan shows how the socio-economic development of a region depends on demographic parameters. All this makes relevant the research aimed at the study and analysis of the reasons for the reduction of the rural population. The study of demographic processes in Tatarstan, using geographic and demographic features at the grass-root territorial level, made it possible to identify stable zones which composition included several regions of administrative regions differing in the course of their demographic processes, what would allow this experience to be used in other territories. The analysis and elaboration at the level of an individual constituent entity made it possible to identify regional features and develop practical recommendations for the transition to regional sustainable development. For a better disclosure of the topic under study, the comparative data of urban and rural populations are used in many ways.

Accordingly, concrete results were obtained and practical recommendations were proposed as a result of the study, which should be implemented in the very near future. Modern trends in the development of the rural population were specified in the work.
\end{abstract}

Keywords: Rural Population, Rural Population Forecast, Rural Area, Village, Rural Displacement

\section{Introduction}

Analysis of the population, its size, composition and location, social organization and economic activity is an important part of any socio-economic and territorial study. Therefore, interest in human population issues goes back to ancient times. The population is an indispensable element of the characteristic of the world in general, and of the countries, and of the regions, and of individual settlements. Population problems are currently being discussed at meetings of various representative commissions and specialists from other regions of Russia and CIS countries and the world, as evidenced by a huge number of dissertations performed by Tatarstan scientists. There are constantly emerging new situations with the closest possible connection to and directly affecting the population, including the rural population. These situations include issues related to the resettlement of the population, the formation of a

modern labor market, the restriction of excessive growth in large cities, modernization of the village infrastructure, changes in the social structure of rural areas, improvement of quality and living standards of the rural population, the reduction of crime, the development and modernization of entrepreneurship, etc. More than 7.4 billion people live on the globe, and almost half of them live in rural areas. Russia is among the highly urbanized countries of the world. In Russia, the rural population is only $24 \%$ of the total population of the country. Today, we are talking about $35 \mathrm{mln}$.

At the same time, in a number of regions of the Russian Federation, significant positive experience has been accumulated in the complex development of rural areas, the development of rural social and engineering infrastructure, housing construction, financial support for the economic activity of the rural population, and the expansion of its employment. For example, such regions include: the Belgorod Region, the Leningrad Region, the Republic of Mordovia, the Chuvash Republic, and other regions. Among such regions is the Republic of Tatarstan.

This experience is worthy of attention and generalization for the purpose of use in other constituent entities of the Russian Federation, as well as at the federal level when developing programs for the development of the Russian rural areas and rural community.

Rural areas and rural community play an important role in the socio-economic life of modern society. The Russian rural community goes through changes related to the deepening of social differentiation, as well as social stratification of rural society. Even recently being relatively homogeneous in terms of its basic property criteria, rural community is structured into new social strata and groups as a result of different forms of ownership [1].

The problems of the present social unhappiness of the native rural areas are such that they jeopardize the continued existence of Russian statehood and make it impossible to ensure the sustainable development of Russian society.

\section{Methods}

To conduct the study, methods of structural analysis, prediction, extrapolation, and the comparative analytical method were used. 
To understand the features of rural development, the works of both domestic and foreign scientists have been analyzed and summarized.

\section{Results}

The comparison of urban and rural populations with many parameters is often used. It turns out that urban population excels rural one by virtually all the main indicators that characterize the level and quality of life of the population. The corresponding differences are maintained between the urban and rural areas by demographic indicators also. In most regions of Russia, the negative growth of the rural population determines the overall decrease in the population in the region. The number of children in rural areas is declining faster than in the urban ones [2]. Almost half of migrants from rural areas are young people. Statistics shows that the number of children in rural areas is decreasing more rapidly than in the urban ones.

The population of Tatarstan, as well as other regions of Russia, is very mobile, as it is continuously moving for various reasons: for example, from rural areas to cities with the aim to study, to work in industrial production sector, etc. For example, a large number of people in the post-war years were forced to leave the territory of the republic and go to the Urals, Siberia, the Far East, the Donbas and other places to participate in large construction projects and the development of virgin lands. The youth of the republic actively worked in new construction in Western and Eastern Siberia; and from the mid-sixties of the 20th century in all-Union significance construction directly in the region, in the city of Naberezhnye Chelnyin construction of KamAZ automobile plant, in construction of the Zainskaya GRES power plant and the Nizhnekamsk petrochemical plant. At the end of the 20th and beginning of the 21 st centuries, under the conditions of migration, it becomes practically the real source of the population growth in the republic. The overwhelming majority, about $90 \%$ of all people arrived in the region were migrants from almost all union republics of the former Soviet Union. But a record number of migrants was reached in the 90 years of the twentieth century, when the flow of population from the CIS countries had increased, especially from Uzbekistan, Kazakhstan, Ukraine, Azerbaijan, Armenia, Tajikistan, etc. during the economic crisis. [3].

The dynamics in the number of Russians and Tatars from the total population of the region for 1920-2010 is of interest. For example, from 1926 to 1989, the proportion of Russians and Tatars living in the republic from the total number of the region's population changed insignificantly. For the selected period, the number of Tatars decreased by $0.2 \%$, while it was observed even $0.1 \%$ increase for the Russians. It's amazing that during this time the Tatar population in numerical terms grew by as much as 548 thousand people, and the Russian population by 500 thousand persons [4].
The 2010 population census showed a generally positive trend in the demographic development of the republic. Positive shifts spoke about the reproductive, social and economic potential of the republic [5].

As of January 1, 2016, there were 3,077 rural settlements in Tatarstan. This is 912.8 thousand people, or $23.6 \%$ of the population of the republic in absolute terms.[6]For comparison, in 2006 the rural population of the republic was 957.8 thousand people, or $25.5 \%$ of the population in the republic [7]. With regard to our calculations using the extrapolation method, the rural population of Tatarstan by 2030 may significantly decrease and make up less than one fifth in the total population in the republic (in absolute terms it is 813 thousand people).

Despite the overall favorable demographic situation in the region according to state statistics, from 1996 to 2006 , the number of rural population of the Republic of Tatarstan has decreased by approximately 50 thousand people. This is despite the fact that in 1989-2002, 166 thousand people from the CIS states arrived in the republic, most of whom chose the countryside [8].

Tatarstan is currently developing with confidence, solving the following important tasks: the growth of economic potential; increase in the level and quality of life of people; and infrastructure development [9]. These directions are considered urgent tasks for the rural population also.

The importance of issues on optimizing the territorial organization of the population grows in the difficult conditions for the demographic development of the country as a whole [10]. The importance of this issue for rural areas increases: almost a quarter of the population lives and the absolute majority of settlements of various types are concentrated there. In addition, although less quantitative in scale, but more intensive in relative magnitude, depopulation processes are characteristic of the rural community. The demographic future is essentially vague, which must be taken into account in socio-economic solutions, including marketing, financial and others.

The corresponding uncertainty is created mainly due to the complexity of understanding demographic processes, imperfect demographic data, unpredictability of migration policy, and a number of other phenomena $[11,12,13]$.

\section{Discussion}

Demographic processes have the pronounced territorial differences. In particular, for 2017-2030, the population of Apastovsky, Rybno-Slobodsky, Baltasinsky municipal districts maybe more than halved. According to the projected estimates, the Kamsko-Ustinskii and Verkhneuslonsky municipal districts may significantly lose their population. In the course of the study it was found out that for these 
regions there is a significant isolation of many settlements from the regional center. For these areas, the transport problem remains extremely important $[14$, 15]. Therefore, it is necessary to solve the problem of isolation of rural settlements, ensuring their interrelation with each other, and with district centers. Urbanization of the countryside by creating prerequisites for the re-emigration of citizens to rural areas on the terms of permanent residence or seasonal residence can be one of the ways to solve this complex problem.

To implement this in the very near future, it is necessary:

- Development of conceptual proposals on the formation and optimization of a uniformed rationally organized network of populated areas (a resettlement system) on the territory of the regions;

- Development and improvement of a strictly coordinated hierarchy of the resettlement system;

- Creation of a ranked set of different centers of territorial resettlement systems based on their role in the current resettlement system, with an emphasis on the all-round development of local resettlement systems.

Particular attention should be paid to improving the territorial resettlement systems in problem areas, which will allow:

- To mitigate existing disproportions and deformations in the resettlement system;

- Increase the overall level of social and cultural services for the population;

- Create conditions promoting the most effective development and deployment of the productive forces of these regions.

The importance of the issue on the optimal productive forces allocation in problem areas in the countryside is connected with the complexities of rational allocation of rural settlements and the population living in them. This is due to the fact that only a small part of the settlements is part of territorially-related resettlement systems, a significant part of them are on the periphery.

Therefore, there is a need to form a viable system of rural settlement, the boundaries of which ideally coincide with the boundary of an administrative district [17]. The formation of this system is primarily aimed at providing the population of the respective regions with equivalent access to social and cultural services of different rank.

The primary objectives for the formation of such a backbone system-forming framework for the resettlement of rural areas include:

- Building up the social and economic potential of local centers of the agro-industrial complex and transforming them into complex developed centers and sub-centers;
- Development of intensive production, economic, labor, social and other links of local centers with peripheral settlements of the regions;

- Creation of necessary road and transport prerequisites ensuring the implementation of stable inter settlement links.

To realize the social potential of a center of such a resettlement system, it is necessary to create and maintain complexes of facilities and institutions for social and cultural services designed to provide the entire population of the local resettlement system with a full set of standard and partially specialized services of occasional demand.

In the case of group settlement, the territory of the districts should be filled with elements of transport engineering and socio-cultural infrastructures, and their city-forming and social potential of a center and subcenters should be increased.

There is a need to form key points in the rural settlement network that serve as centers for social, cultural and trade-and-household services for a group of populated areas. There is also a need for creation of new rural settlements built according to modern projects, taking into account their labor potential, prospects for production development, including nonagricultural activities, forecasting the development of natural demographic and migration processes.

Of particular importance in improving the territorial organization of rural settlements is ensuring the viability of small settlements (village councils) by supporting production, improving the territory, building day-to-day service facilities, and covering the population with mobile and remote services.

The network of settlements within the boundaries of a rural municipal district and municipal settlements should be a set of actively interacting urban and rural settlements based on the development of transport and other modern types of infrastructure.

Such a purposeful resource-saving organization of the settlement network will serve as an important factor in the demographic stability of rural areas as a socioeconomic and territorial subsystem of society.

Ultimately, a rational territorial organization of the rural population will contribute to the sustainable development of rural areas. At the same time, the growth, diversification and efficiency of the rural economy will be ensured; reproduction and improvement of the quality of human resources, full and productive employment of the able-bodied population; improvement of the quality of life in rural settlements, rational use and reproduction of natural resources.

\section{Summary}

As a result of the study, the following conclusions were obtained: 
1. In general, rural settlements in Tatarstan still have a sufficiently high agricultural resource, demographic and labor potential.

2. The crisis situation in the future can be formed only in several regions of the republic. A detailed analysis of the resettlement system of these territories shows that many problems lie in dispersed population resettlement.

3. An assessment of the relationship between the time variations of the rural local resettlement systems parameters values has showed that the population density of most of their types and subtypes is related to the change in the average number of settlements.

4. The change in the average population of rural local resettlement systems is primarily due to a change in their territorial scope, which is largely determined by state policy in the sphere of grass-roots administration management and agricultural production.

5. The critical limit of the number of rural settlements is elaborated, what is necessary to preserve the rural form of settlement in Tatarstan. Calculations show that this is 11-12 people. Density of districts with a number of people less than 6 people for $1 \mathrm{sq}$. $\mathrm{km}$ will only lead to significant expenditures from the republican budget and in the future the issue of enlarging the districts may become much more urgent.

6. Preservation of the existing settlement network in the whole variety of existing forms of rural settlement depends on the specific conditions and characteristics of the area. To preserve the optimal network of rural settlements in Tatarstan, areas with a population of 2030 thousand people should be preserved, while the population density must correspond to 25-32 people for 1 sq. $\mathrm{km}$.

7. All municipal areas adjacent to the city of Kazan have a high positive migration increase in the population. But, in spite of this, according to the predicted calculations, only in Pestrechinsky the population is expected to grow.

8 . For the Tatars, settlements with a population of 50100 and 200-500 people and those with more than 1,000 people should be considered more favorable for population growth. On the contrary for Russians, it is these groups in terms of population quantity intervals that have negative indices. For Russians, only one type of settlement is favorable for the growth of their share, where the population is within the range of 500-1000 people.

9. An analysis of the demographic processes in Tatarstan using geo demographic features made it possible to identify stable zones consisting of several administrative regions with a different demographic process, what demonstrates the need to pursue a separate demographic policy in various regions of the Republic of Tatarstan and take these zones into account when predicting the population.

\section{Conclusion}

The study of demographic processes in Tatarstan with the use of geo demographic features at the grass-roots territorial level made it possible to identify stable zones, the composition of which included several administrative regions differing by the course of demographic processes. The results obtained dictate the need to pursue a separate demographic policy at the regional level in Tatarstan. These data serve as ready material for population forecasting.

According to the study materials, the stably negative zones will survive. Processing of the results of the study made it possible to identify the formation of two stably negative zones in areas with a predominance of Russians. Feature of the allocated zones: low fertility and high mortality. They are regions near the Volga River and the city of Kazan, and territorially it is in these zones: Verkhne-Uslonsk, Kamsko-Ustinsk, Tetyushsk, Zelenodolsk districts. The second zone was formed in the Northeast of the republic and includes Zainsk, Elabuga, and Nizhnekamsk districts.

The growth of cities within these zones, such as Kazan, Zelenodolsk, Yelabuga, attracting internal migrants from rural areas had a decisive impact on the change in the sex and age structure in the rural population of these areas.

\section{Acknowledgements}

The study was carried out with the financial support of the Russian Foundation for Basic Research and the Republic of Tatarstan, the project "Forecast Assessment of the Social and Economic Development of Rural Settlements in the Republic of Tatarstan" No. 17-12-16005.

The work is carried out according to the Russian Government Program of Competitive Growth of Kazan Federal University.

\section{References}

[1]Ziyatdinova F.G., Kuchaeva E.I. Russian rural areas in market conditions. - M.: UNITY-DANA: Law and Rules, 2008. - 199 p.

[2]Akhmetgaliyeva A.R. Specificity of the manifestation and factors of the demographic crisis in the rural community // National identity of Russia and the demographic crisis / Proceedings of the Third AllRussian Scientific Conference. - Moscow: Scientific Expert, 2009. - 840 p.

[3]Gaisin, I.T., Biktimirov, N.M. Migration Processes in the Republic Tatarstan in the Second Half of the 20th and in the Early of 21st Centuries: Ethnic and Social Aspects. Middle-East Journal of Scientific Research

20(12):17611766,2014http://www.idosi.org/mejsr/mejs r20(12)14/12.

[4]Biktimirov, N.M., Gaisin, R.I., Gaisin, I.T. The use of methodologies for demographic investions in national-territorial subdivisions of Russia. Life Science Journal. 2014;11(8 p) P.194-197.

[5]Safiullin, M.R., Elshin, L.A., Shakirova, A.I., Ermolaeva, P.O., Prygunova, M.I. (2013). Influence of Territorial Ecological Load Factors on Social and Economic Well-Being of Population: Methodology 
Development and Econometric Model Construction. World Applied Sciences Journal 25, 7, 1057-1061.

[6]Republic of Tatarstan, 2016, Statistical handbook.

Tatarstanstat, Kazan, 2016 - 39 p.

[7]Number, composition and movement of the population in the Republic of Tatarstan in 2008: Statistical Digest / Tatarstanstat. - Kazan: Publishing Center of Tatarstanstat 2009 - 136 p.

[8]Cities and regions of the Republic of Tatarstan in figures. Statistical collection. - Kazan: Tatarstanstat, 2009.

[9]Bagautdinova, N., I. Gafurov, N., Kalenskaya and A. Novenkova, 2012. The regional development strategy based on territorial marketing (the case of Russia) World Applied Sciences Journal, 18. SPL.ISSUE., 18: pp.179-184.

[10]Gabdrakhmanov, N.K., Rubtzov, V.A., Baybakov, E.E., Ulengov, R.A. Role of space and stability in the development of tourism (Article)//Academy of Strategic Management Journal Vol. 15, Special Issue 2, 2016, pp.32-37.

[11]Hyndman R.J., Booth H. (2008) Stochastic population forecasts using functional data models for mortality, fertility and migration. International Journal of Forecasting 24: 323-342 doi:10.1016/j.ijforecast.2008.02.009

[12]Rubtzov, V.A., Gabdrakhmanov N.K., Delabarr, O.A., Tyabina, D.V. Equilibrium tasks in geography // Mediterranean Journal of Social Sciences 6 (3), pp. 669-672

[13]Rubtzov, V. A., Rozhko, M. V., Gabdrakhmanov, N. K., Gilmanova, A. A. Competitiveness and positioning of municipalities in the republic of Tatarstan // Mediterranean Journal of Social Sciences, 6(3), 761-765

[14]Rubtsov, V.A., Gabdrakhmanov N.K., Mustafin, M.R., Arzhantseva, N.V. Optimization model of making a decision in the conditions of uncertainty (correlation of interests and preferences in regional systems) // Mediterranean Journal of Social Sciences 6 (3), pp. 781-785

[15]Rubtsov, V.A., Gabdrakhmanov N.K., Mustafin, M.R., Arzhantseva, N.V., Trofimov, A.M. Field theory in geography and stable structure of geoformations // Mediterranean Journal of Social Sciences 6 (3), pp. 673-676

[16]Biktimirov, N., Gabdrakhmanov N.K., Rubtsov, V., Mustaphin, M., Arzhantseva, N. Peculiar features of the Tatar people migration on the territory of Tatarstan // Mediterranean Journal of Social Sciences 5 (24), pp. 267-271

[17]Rubtzov, V.A., Gabdrakhmanov N.K., Mustafin, M.R., Pratchenko, O.V. Geodemographic potential of the republic of Tatarstan: Analysis, evaluation, territorial differences // Mediterranean Journal of Social Sciences 5 (24), pp. 278-284 